\title{
MoNSTROS, MÁQUINAS E PIPOCAS: TEATRO DO OPRIMIDO E PROTESTO DE RUA
}

\author{
Inês Barbosa \& Fernando Ilídio Ferreira
}

\begin{abstract}
Resumo
Este artigo parte da experiência do Núcleo de Teatro do Oprimido de Braga no contexto das movimentações levadas a cabo, em Portugal, contra a austeridade, entre 2012 e 2013 . Apresenta algumas das intervenções políticas e artísticas do grupo, bem como uma reflexão sobre o seu impacto e limitações. Pretende-se analisar as possibilidades de o Teatro do Oprimido (TO) intervir, influenciar ou potenciar o protesto de rua e, ao mesmo tempo, examinar em que medida pode esta experiência articular e interpelar as duas dimensões de crítica do capitalismo, social e estética, enunciadas por Boltanski e Chiapello na obra $O$ novo espírito do capitalismo. A investigação insere-se numa perspetiva de investigação interventiva e participativa, procurando conceber e situar o TO enquanto ferramenta de ação coletiva e educação crítica, no âmbito das mobilizações sociais contemporâneas.
\end{abstract}

\section{Palavras-chave}

Austeridade; crise; crítica; mobilizações sociais; teatro do oprimido

\begin{abstract}
This article rises from the experience of the Theatre of the Oppressed Group from Braga in the context of the movements carried out in Portugal against austerity between 2012 and 2013. It presents some of the political and artistic interventions of the group, as well as a reflection on their impact and limitations. We intend to analyze the possibilities of the Theatre of the Oppressed (TO) to intervene, influence or enhance street protest and, at the same time, examine the extent to which this experience can articulate and question the two critical dimensions of capitalism, social and aesthetics, enunciated by Boltanski and Chiapello in their work $O$ novo espirito do capitalismo [The new spirit of capitalism]. This article is part of an interventionist and participatory research perspective, that seeks to conceive and frame the TO as a collective action and critical education tool, within the context of contemporary social mobilizations.
\end{abstract}

\section{Keywords}

Austerity; crisis; criticism; social mobilizations; theatre of the oppressed

\section{INTRODUÇÃo}

Palavra, imagem e som, que hoje são canais de opressão, devem ser usados pelos oprimidos como formas de libertação. Não basta consumir cultura, é necessário produzi-la. Não basta gozar arte: necessário é ser artista! Não basta produzir ideias: necessário é transformá-las em atos sociais, concretos e continuados. (Boal, 2009, p. 19) 
Augusto Boal (1931-2009), dramaturgo e criador do Teatro do Oprimido (TO), proferiu estas palavras no Fórum Social Mundial, em Belém, poucos meses antes de nos deixar. Este apelo de Boal é especialmente mobilizador no contexto de crise e austeridade em que Portugal se encontra. Desde o despoletar da crise e da consequente intervenção da Troika em $2011^{1}$, sucessivas medidas de austeridade foram implementadas e, embora anunciadas como conjunturais, têm-se perpetuado com um carácter ideológico, legitimando a reestruturação das relações e do direito de trabalho, a acentuação da fragmentação social, o enfraquecimento das solidariedades coletivas, o desmantelamento do Estado Social (Abreu et al., 2013; Ferreira, 2012). Assim, mais do que um mero conjunto de opções de política económica e social, a austeridade tem prosperado pela "fabricação do consenso" (Chomsky, 2000), através da manipulação da opinião pública pelos media (Monteiro, 2011); pela criação de "mitos do senso comum" em torno da austeridade (Soeiro, Cardina \& Serra, 2013); pela precarização do trabalho (Ferreira, 2012; Soeiro, 2015); pelo esvaziamento do espaço público e, de um modo geral, pela "cultura de medo" (Furedi, 2006) que inibe a mobilização social e política e alimenta a resignação.

Contudo, estas transformações não têm ocorrido sem resistência. Acompanhando a contestação global e, em particular, as mobilizações e "movimentos da crise" - "pró-democracia e anti-austeridade" (Della Porta, 2014) - que ocorreram em vários países, particularmente do sul da Europa, Portugal protagonizou, entre 2011 e 2013, um ciclo de protestos intensos e continuados (Estanque, Costa \& Soeiro, 2013). Ainda que histórica e tradicionalmente frágil na sua organização e mobilização civil, o país viu-se atravessado por greves, manifestações, ações diretas, protagonizadas por coletivos que se sucediam uns aos outros - Movimento 12 de Março, Plataforma 15 de Outubro, Que se Lixe a Troika, etc. - e também por sindicatos, partidos de esquerda, associações e movimentos sociais. Estes coletivos combinam formas "clássicas de intervenção política" com "formas mais criativas e transgressivas de ação" e a cooperação com os atores sindicais e partidários revela-se "tensa", "atravessada pelas diferenças de linguagem, de hegemonia política, de culturas de classe que persistem" (Soeiro, 2012, p. 9).

Este artigo baseia-se na experimentação ativista do Núcleo de Teatro do Oprimido (NTO) de Braga, Portugal, adotando o método criado por Boal como ferramenta social e política de mobilização e protesto. Mais do que um conjunto de técnicas - teatro-invisível, teatro-imagem, teatro-fórum, arco-íris do desejo, teatro-legislativo, estética do oprimido - o TO possui uma história e desenvolvimento particulares. Influenciado por Bertolt Brecht, no campo teatral, e por Paulo Freire, no campo educativo, o TO foi idealizado e concebido, no início dos anos de 1970, no contexto da ditadura brasileira. De inspiração marxista, o método coloca no centro da análise os sistemas de opressão e os desequilíbrios de poder, tendo em vista a sua superação e a transformação social. Em 1970, em resposta à repressão e censura e ainda influenciado pelo teatro de agit-prop - agitação e propaganda (VC, 2007, p. 12) - dão-se as primeiras experiências com

\footnotetext{
' A Troika é a entidade que junta Banco Central Europeu, Comissão Europeia e Fundo Monetário Internacional. Em Portugal, a presença da Troika assinalou-se entre 17/05/2011 e 17/05/2014, contudo, as medidas de austeridade e a vigilância externa manter-se-ão durante os próximos anos.
} 
teatro-jornal, considerada a "semente do teatro do oprimido". Em 1971, Boal é preso, torturado e parte em exílio. É nesses treze anos fora do Brasil que a semente germina dando origem à maior parte do seu arsenal.

Ainda que a algumas das técnicas seja atribuída uma natureza normativa e até terapêutica, a perspetiva do método que aqui exploramos é a do "teatro político" na sua dimensão emancipatória, inscrito na história do "pensamento crítico" (Neveux, 2014; Rancière, 2010). "Um ensaio da revolução" foi o que Boal chamou ao TO, pois nele se testam resistências e se procuram alternativas (Boal, 1980). É nesta perspetiva que o artigo incorpora dados que pretendem salientar a aprendizagem experiencial crítica do grupo, em termos individuais e coletivos, associada à ação político-artística do protesto de rua.

\section{Metodologia}

O grupo NTO Braga foi criado em 2011 através do impulso de um grupo de amigos, entretanto constituído em associação Krizo - Educação, Arte e Cidadania ${ }^{2}$. A militância é fluída e intermitente. Há um núcleo de cinco elementos que se mantém desde o início e que vai impulsionando e motivando outras pessoas a colaborar. A intermitência deve-se, em boa medida, à condição precária dos jovens que integram o grupo. Há quem tenha emigrado; quem esteja desempregado; quem esteja novamente a estudar, na esperança de aumentar a sua inserção laboral; ou quem acumule dois ou três trabalhos para fazer face às despesas. Desde o surgimento do NTO/Krizo, o grupo tem vindo a organizar diversas iniciativas - debates, workshops, exposições, concertos, instalações artísticas, sessões de teatro-fórum, encontros políticos, vídeo-ativista, etc. - envolvendo-se em projetos locais, nacionais e internacionais. Os membros consideram-se "subversivos, porque não estão de acordo com a lógica dominante, e insistentes, pois não desistem facilmente". Movem-se pela "procura coletiva de alternativas": "pesquisar, refletir, consciencializar, debater a fundo e com muita gente." 3

O presente trabalho expressa várias inquietações: que papel pode ter o TO no protesto e no resgate da rua? O que traz de importante ou de novo? De que forma pode intervir, influenciar ou potenciar o espaço público? Qual a relação dos chamados "artistas" com outros sujeitos políticos? Inspirada nas perspetivas da investigação participativa (Fals Borda, 1991; Freire, 1981) e de uma sociologia pública e militante (Braga, 2011; Burawoy, 2006), a investigação envolveu a observação participante, com registo em diário de bordo; um grupo focal com membros do grupo realizado em 2014; e a análise de fontes documentais: notícias de jornal, fotografias, cartazes, vídeos, convocatórias dos movimentos/sindicatos, o guião de uma peça de teatro-jornal e textos publicados nas redes sociais. A análise pretende aproximar-se do carácter narrativo da auto-etnografia (Denzin, 2014) e da etnografia militante (Juris, 2007).

\footnotetext{
${ }^{2}$ Retirado de https://www.facebook.com/ajkrizo

${ }_{3}^{3}$ Retirado de http://www.comumonline.com/cultura/item/844-teatro-do-oprimido-de-braga-agita-a-cidade-dos-arcebispos; http://www.comumonline.com/?p=1240
} 
Ao mesmo tempo, e recorrendo à obra $O$ novo espírito do capitalismo, de Boltanski e Chiapello (1999), reflete-se sobre o modo como esta experiência ativista se posiciona face às duas dimensões da crítica do capitalismo que estes autores enunciam: a crítica estética e a crítica social. Pretende-se contribuir para a compreensão das articulações e interpelações que os dois registos críticos expressam na atualidade, cruzando a análise da dinâmica interna do grupo ativista (NTO) com a reflexão em torno de fatores societais, especificamente no contexto das movimentações sociais contra a austeridade e a Troika, em Portugal.

\section{A CRISE, A Troika E O ReSGATE DA RUA}

No período de 2012-2013, correspondente ao pico de mobilizações contra a austeridade, o grupo protagonizou uma série de iniciativas de rua nos vários protestos que se iam dando pelo país e, de forma mais discreta, em Braga. Optou-se por incluir aqui o relato de quatro momentos específicos - 13 de outubro de 2012 (Manifestação Cultural); 14 de novembro de 2012 (Greve Geral da CGTP); 2 de março de 2013 (Manifestação "Que se Lixe a Troika"); e 1 de maio de 2013 (Dia do Trabalhador) - em que a intervenção do NTO apresentou características distintas em relação ao tipo de protesto, tempo de preparação, estratégias, participantes ou objetivos. Foram utilizadas técnicas de teatro-jornal e teatro-imagem, mas acima de tudo as intervenções enquadram-se nos princípios da Estética do Teatro do Oprimido e na apropriação e democratização da rua, da arte e da política.

\section{SALAZAR, Troika E O MONSTRO DA CRISE}

Manifestação Cultural "Que se lixe a Troika", 13 de outubro de 2012

Nessa reunião estariam presentes umas doze pessoas (...) uma parte andaria pelos 50 anos - os militantes de Abril - e outra pelos 25-30 anos. Parecia haver pequenas divergências, não no sentido de conflitos mas de visões diferentes. Os mais velhos propunham música popular e de intervenção, os mais novos falavam de rock e punk. (Diário de bordo, 01/10/2012)

As discordâncias não se limitavam aos gostos musicais. Apesar da escassa participação, a diversidade que compunha as reuniões era muita: idade, escolaridade, origem social e também modos de "fazer política". As diferenças de pontos de vista entre militantes de partidos de esquerda e sindicatos ou pessoas a título individual, membros de associações ou movimentos eram claras. As discussões eram longas, as estratégias não reuniam consenso, as lideranças não eram evidentes e, frequentemente, à saída das reuniões sobressaía o cansaço e alguma irritação.

O texto da convocatória4, assinado por um "conjunto alargado de profissionais do mundo da cultura", com o lema: "cultura é resistência", motivava a participação popular,

\footnotetext{
${ }^{4}$ Convocatória "Que se lixe a Troika" - Manifestação Cultural. Retirado de http://www.precarios.net/?p=167
} 
chamando "todas as formas de arte que materializem o espírito de insubmissão que se sente em todo o país", levando "da rua para a arte e da arte para a rua toda a energia que as percorre". O NTO decidiu participar na manifestação, não só com uma peça de uma peça de teatro-jornal "Troca o Salazar pela Troika"s que já havia sido apresentada nas celebrações do 25 de Abril, mas também na definição da programação e alinhamento, convocação da imprensa, distribuição de folhetos e em tudo o mais que fosse necessárió.

"Sem cultura o homem transforma-se num cão", o arranque da Manifestação, que terá contado com cerca de 1000 pessoas, era dado por Adolfo Luxúria Canibal, vocalista dos Mão Morta e uma das "figuras míticas" de Braga: "quando se chega ao ponto em que se está, em que até no estômago já se sente a crise é porque já passámos por muitos lados. É nesta altura em que o homem se transforma em cão"7. Durante a apresentação da peça, dezenas de pessoas formaram uma clareira à volta do grupo, participando com comentários, gargalhadas, assobios, apupos. A peça propunha-se estabelecer um paralelo entre o discurso de Salazar ${ }^{8}$ e o discurso da austeridade, focando-se na perda de direitos sociais e políticos conquistados na revolução de 1974 e consagrados na constituição9. Recorrendo ao humor, à sátira e à linguagem e a personagens metafóricas, a peça apresentava uma sucessão de cenas interligadas ${ }^{10}$ : uma cozinheira preparava a "receita da austeridade" explicando os necessários "cortes"; a estreia de um filme de terror em que a princesa Lusitânia era atacada pelo Monstro da Crise e salva pelo Alquimista Coelho" (Figura 1); anúncios televisivos aos créditos bancários, à venda de ouro e ao Salazar'2 (rapa-tachos) agora convertido e atualizado num equipamento mais moderno, a Troika; uma sala repleta de "bons alunos"13 obedientes e cumpridores do programa de austeridade; um Gasparzinho' ${ }^{14}$ poupado e honrado ou uma greve às greves. Da programação constavam também concertos, poesia, intervenções políticas, performances (Figura 2).

\footnotetext{
${ }_{5}$ O título da peça "Troca o Salazar pela Troika" refere-se ao discurso da austeridade em diferentes tempos: na época salazarista da ditadura e na época atual.

${ }^{6}$ Retirado de http://www.correiodominho.pt/noticias.php\%20...\%3 C/p\%3E\%3C/noticias.php?id=64775

7 Retirado de http://www.dn.pt/inicio/portugal/interior.aspx?content_id=2826776\&page=-1

${ }^{8}$ Salazar é o nome ligado à ditadura, em Portugal, que durou 48 anos: o mais longo regime autoritário da Europa Ocidental do século XX.

9 Uma análise aprofundada sobre o tema e sobre a utilização da técnica na atualidade pode ser lida no artigo da nossa autoria "O fascismo ainda mora cá dentro? O teatro-jornal e o discurso da austeridade", Revista Educação, Sociedade e Culturas (no prelo).
}

\footnotetext{
${ }^{10}$ Algumas cenas podem ser vistas em https://www.youtube.com/watch?v=7T9Td_DgDZM

"Alquimista Coelho é um trocadilho entre o primeiro-ministro Pedro Passos Coelho e o escritor brasileiro Paulo Coelho, autor do livro O alquimista.

${ }^{12}$ Salazar é o nome dado popularmente ao instrumento que serve para rapar os bolos e combater o desperdício, precisamente por remeter para o sacrifício e contenção dos tempos salazaristas.

${ }^{13}$ A expressão "bons alunos" tem vindo a ser utilizada para descrever o comportamento do governo português face à Troika. Por exemplo: http://economico.sapo.pt/noticias/de-gastadores-a-bons-alunos-a-imagem-de-portugal-melhorou-mas-a-que-preco_218456.html

${ }^{14}$ Gasparzinho refere-se a Vítor Gaspar, à época Ministro das Finanças. A notícia que inspirava esta cena era a que está em http://www.asbeiras.pt/2012/03/vitor-gaspar-foi-a-manteigas-lembrar-ensinamentos-da-avo/
} 


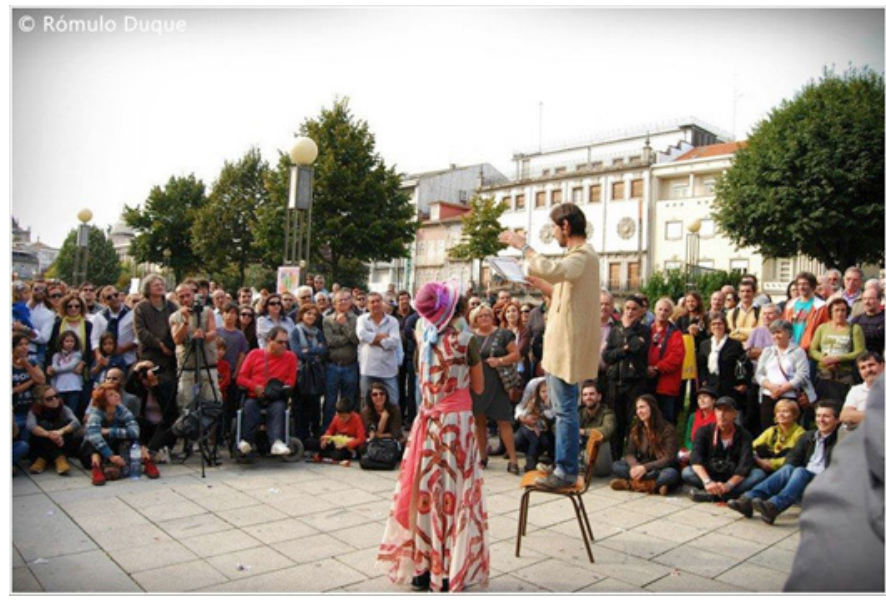

Figura 1: Troca o Salazar pela Troika Fonte: Rómulo Duque

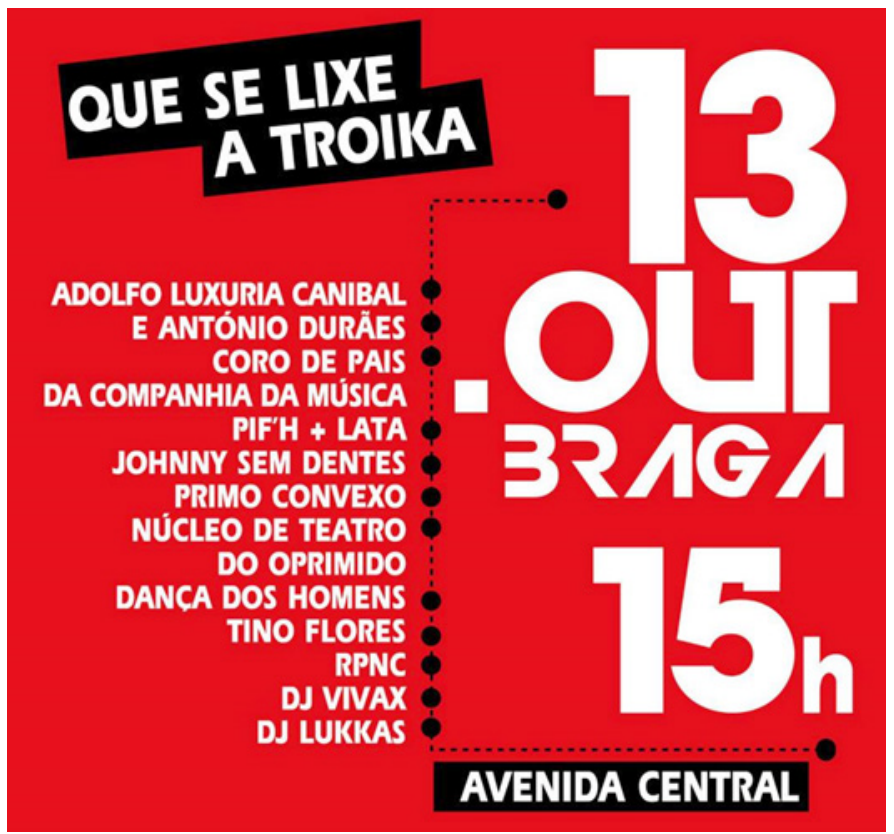

Figura 2: Cartaz da Manifestação Cultural "Que se lixe a Troika" Fonte: Que se lixe a Troika, Braga

No final da atuação o grupo juntou-se na relva conversando com outros amigos e decidiu executar outra ideia: uma instalação plástica do "Monstro da Crise", com o objetivo de denunciar a manipulação mediática em torno do discurso da crise, cuja presença abundante nos jornais suscitava o medo nas pessoas. Tínhamos levado caixas de cartão, tintas, papel de cenário, notícias de jornal e notas de monopólio. Com a ajuda de um amigo grafitter e de mais de uma dezena de jovens construiu-se um monstro com cifrões nos olhos e uma boca aberta da qual pendia uma língua comprida (Figura 3). 


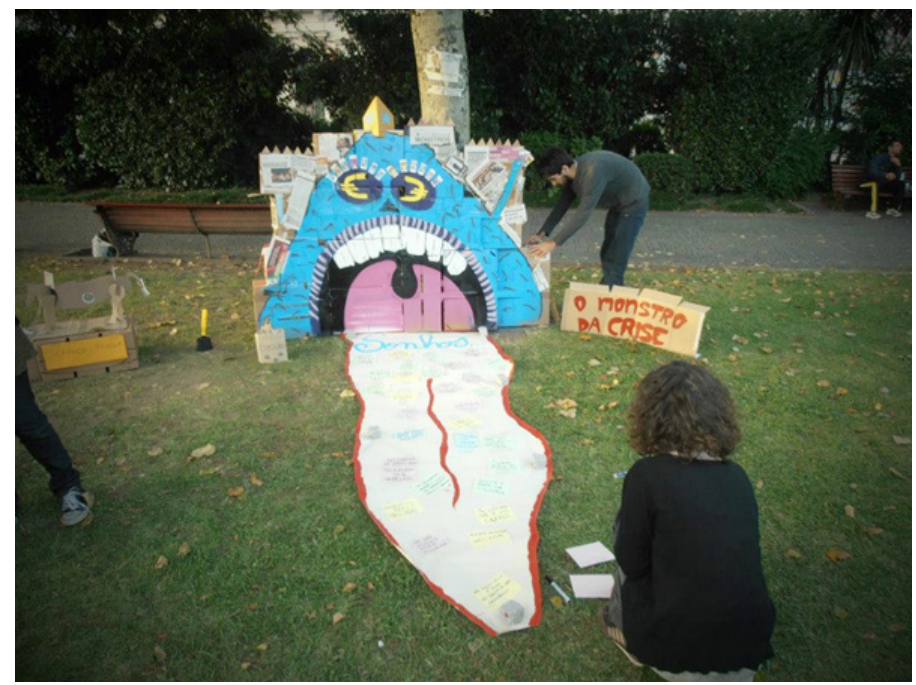

Figura 3: Instalação plástica "Monstro da Crise Fonte: Filipe Fernandes

Circulando pelo recinto da manifestação, elementos do NTO questionavam quem passava: que sonhos lhes estava a roubar o monstro da crise? As pessoas respondiam com vontades e anseios - quero ter um emprego; quero sair da casa dos meus pais; quero ter direito à reforma; não quero ter de emigrar - que eram registados e colados na língua do Monstro, como se eles os estivesse a engolir. No final da manifestação, havia uma sensação de alegria em todos nós: "acima de tudo foi um evento bonito" (Diário de bordo, 14/10/2012).

\section{“Mãos ATADAS” E “ESTÁTUA DA CRISE”}

Concentração/ Greve Geral da CGTP, 14 de novembro de 2012

A rua tem uma energia incontornável. As cerca de trezentas pessoas presentes concentraram-se com bandeiras e faixas, em frente aos microfones, para ouvir os discursos dos dirigentes sindicais. Apesar de não nos interessar minimamente o que apregoavam (nem possivelmente a muita gente que lá estava) esgueirámo-nos para um lugar relativamente afastado, formando uma fila de dez pessoas para a performance dos "representantes da crise. (Diário de bordo, 14/11/2012)

O NTO não tinha sido convidado a participar e a nossa intervenção foi uma espécie de invasão do espaço público. O protesto era convocado pela CGTP, Confederação Geral dos Trabalhadores Portugueses, "contra a exploração", o "empobrecimento" e o "programa de agressão" 15. Juntaram-se vários grupos, em Braga, representados pelo movimento "Que se lixe a Troika"16. Tínhamos preparado duas ideias nos dias anteriores:

\footnotetext{
${ }^{15}$ Pré-aviso de Greve Geral, CGTP. Retirado de http://www.cgtp.pt/materiais-greve-geral-14-11-2012

${ }^{16}$ Retirado de http://rr.sapo.pt/informacao_detalhe.aspx?fid=25\&did=84964
} 
"uma estátua coletiva da crise" que se iria transformar numa "máquina alternativa" e "uma fileira de representantes da crise (precários, desempregados, reformados...)" que, com o megafone, partilhariam a sua situação: "cada uma das pessoas dirá uma frase, a seguir é-lhe retirado o megafone (a voz) e as suas mãos amarradas com um pano (mãos atadas, impotência)", "queremos que as pessoas se lembrem que atrás dos números estão pessoas, histórias reais, que têm de ser vistas e ouvidas" (Diário de bordo, 08/11/2012). A preparação não tinha ido além disso, sem ensaios, apenas com a elaboração conjunta de ideias, a distribuição de tarefas e a recolha do material necessário.

Não estaria muita gente presente, os números divulgados oscilam entre 300 pessoas na concentração e 1500 na marcha que se seguiu. Apesar disso a adesão à greve chegava a $100 \%$ em alguns sectores ${ }^{17}$. Quando chegámos ao local da concentração, a impressão de estarmos a invadir acentuou-se. Por momentos hesitámos, receosos de estarmos a ser "indelicados" apresentando uma performance no momento em que se faziam discursos. Porém, decidimos fazê-lo. Como precisávamos de "reforços", chamámos alguns amigos presentes, explicando a performance e pedindo que participassem. O grupo dispôs-se em linha, ostentando numa tabuleta ao pescoço uma frase que resumisse a sua situação (Figura 4).

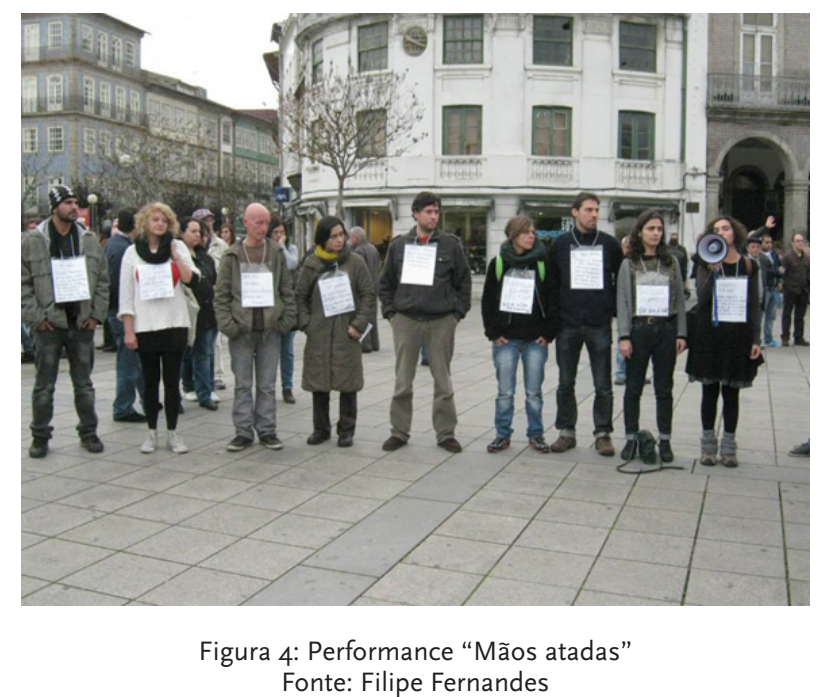

Cada um proferiu a frase que havia decidido: "Helena, recibos verdes, dívida à segurança social de 423 euros"; "Tatiana, 30 anos, vivo ano a ano"; "João, 35 anos, sou professor das A.E.C.s e recebo menos que o salário mínimo"; "Paulo, 30 anos, licenciado, não me resta mais nada a não ser emigrar"; "Marcelo, 33 anos, desempregado, não tenho presente, quanto mais futuro". Um senhor pedia insistentemente o megafone para também poder expressar as suas mágoas. O facto de aparentar algum desequilíbrio (psíquico ou por estar embriagado) fez com que ficássemos receosos do que diria ou do que isso provocaria e acabamos por não permitir. Depois dessa intervenção, aproveitamos a clareira que se formou à nossa volta e abrimos uma manta circular no chão,

${ }_{17}$ Retirado de http://www.tvi24.iol.pt/sociedade/mabifestacoes/greve-geral-retrato-de-um-pais-em-manifestacao 
delimitando o espaço. Um a um lemos ao megafone cabeçalhos de jornais apresentando pouco mais do que números: emigração, abandono escolar, pobreza, desemprego, falências (Figura 5).

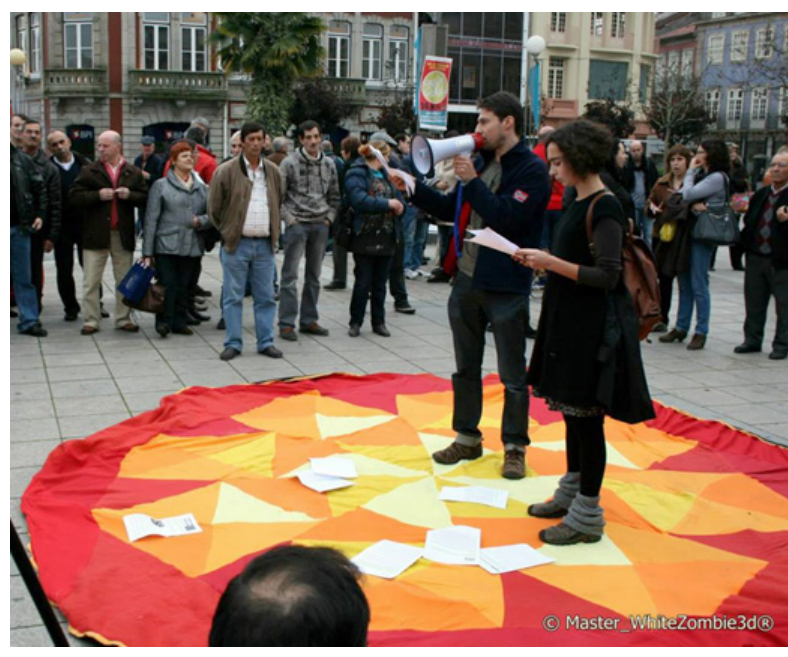

Figura 5: Estátua da Crise (Leitura de cabeçalhos) Fonte: Filipe Fernandes

Através do teatro-imagem procurava-se que esses números fossem convertidos em estátuas humanas: como é que o corpo responde à crise? Procurávamos tornar visível o invisível: os números eram traduzidos em pessoas e vidas concretas. As pessoas que nos rodeavam olhavam atentamente, algumas emocionavam-se e comentavam entre si. O desafio era depois lançado: modificar essas imagens, esculpindo outras em que pudessem ocorrer transformações (Figura 6).

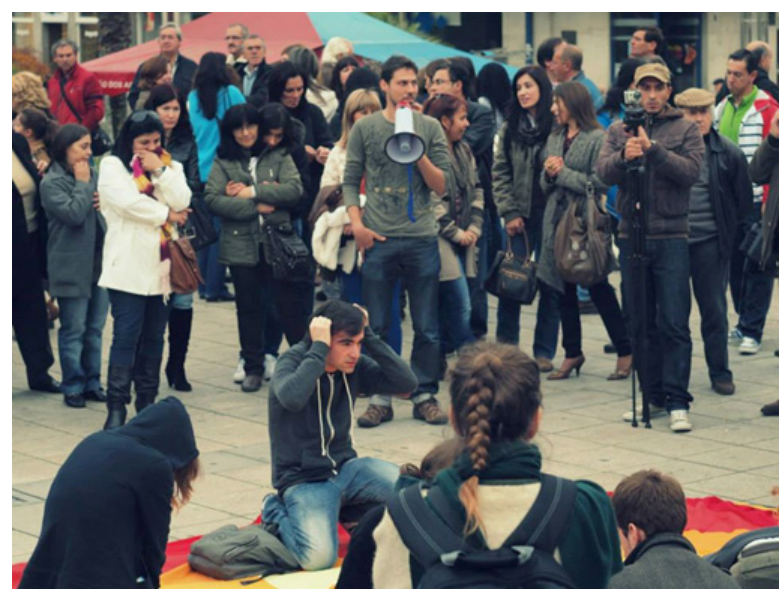

Figura 6: Estátua da Crise Fonte: Filipe Fernandes

Quando lhes pedimos que nos dessem alternativas, que sugerissem saídas, respondeu-nos o silêncio. Minutos depois, um dos senhores presentes agarrou numa das estátuas e retirou-a do círculo. Foi um momento 
assombroso, as pessoas bateram palmas e notava-se o alívio. Seguiram-se

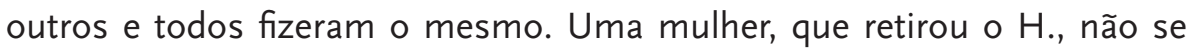
conteve e desatou num choro. Foi arrepiante. (Diário de bordo, 14/11/2012)

No final das intervenções a adrenalina era muita. Outros amigos tinham-se, entretanto, juntado a nós. Movidos pela vontade de provocação e confronto, decidimos levar a primeira performance - "mãos atadas" - a outro lugar. Primeiro pensámos num Banco, mas lembrámo-nos que estava fechado, decidimos fazê-lo então na Loja do Cidadão. Em menos de cinco minutos fomos abordados por um segurança que nos obrigou a cessar a performance. A saída foi entre risadas, "ficámos com vontade de repetir", com a consciência de que precisávamos de "nos informar relativamente às questões legais, o que é ou não permitido, de forma a que nos pudéssemos defender" (Diário de bordo, 14/11/2012). Em Lisboa, as notícias eram de violência'18.

\section{A “MÁQUINA DO EMPREENDEDORISMO”}

"Que se lixe a Troika": o povo é quem mais ordena, 2 de março de 2013

Mal entrámos, um senhor disse: "Olha ainda bem que chegaram os companheiros do TO, para decidirmos qual a melhor altura para fazerem a ação". Parece que já começamos a ser uma entidade reconhecida publicamente. (...) Outro pormenor engraçado foi quando um dos técnicos de som se referiu ao NTO dizendo "temos de ter cuidado com os tempos e espaços onde o NTO vai fazer a apresentação, já sabem como é a sensibilidade dos artistas". Eu, que estava ao seu lado, fiquei ofendida. Resmunguei qualquer coisa tipo: "nós não somos artistas, somos ativistas", mas ficou por aí que não era hora nem local para discussões filosóficas. (Diário de bordo, $01 / 03 / 2013)$

$\mathrm{Na}$ altura da manifestação do 2 de Março, o NTO já tinha participado em quase uma dezena de iniciativas de rua e, em Braga, começávamos a ter alguma notoriedade. Provavelmente, por esse motivo, pediram-nos que abríssemos a manifestação com uma intervenção. Esse reconhecimento era dúbio, pois não queríamos ser vistos como um grupo de teatro mas sim como ativistas políticos. Marcar essa diferença parecia-nos importante. Optámos por apresentar uma performance que havíamos criado durante o Óprima - Encontro de Teatro do Oprimido e Ativismo' ${ }^{19}$, decorrido uns dias antes, em Braga.

A performance "Máquina do empreendedorismo" 20 tinha sido preparada a partir de um exercício de Julian Boal: sequência alegórica de análise. Analisávamos o discurso do

\footnotetext{
${ }^{18}$ Retirado de http://www.publico.pt/economia/noticia/greve-ao-minuto-1572391

19 O Óprima é um encontro anual realizado desde 2012. Atualmente é organizado pelo NTO Braga/Krizo, Tartaruga Falante, KSK Arrentela e Marcha Mundial das Mulheres-Lisboa. Em 2013 realizou-se em Braga. Retirado de https://oprima. wordpress.com

${ }^{20}$ Retirado de https://www.youtube.com/watch?v=eRS3HP8nTZQ ou http://krizontobraga.foliohd.com/\#semana-da-juventude
} 
empreendedorismo em tempos de crise, respondendo a seis perguntas ${ }^{21}$ e recorrendo à linguagem metafórica, ao som e ao ritmo. A sequência procurava representar os vários mecanismos envolvidos no discurso do empreendedorismo - suas estratégias e seus objetivos - tendo em conta o panorama da crise e da austeridade.

O texto da convocatória ${ }^{22}$ da plataforma "Que se lixe a Troika" refletia o clima vivido na época, com o desespero a subir de tom - "não aguentamos mais o roubo e a agressão". As palavras repetiam-se, no plural - indignamo-nos, revolta-nos, resistimos. "Tudo isto é Troika", lia-se: "a Troika condena os sonhos à morte, o futuro ao medo, a vida à sobrevivência". E rematava: "a esta onda que tudo destrói vamos opor a onda gigante da nossa indignação e no dia 2 de março encheremos de novo as ruas".

Em Braga estariam cerca de 7.000 pessoas e, além da nossa performance, juntaram-se alguns músicos com guitarras e outros instrumentos. A alegoria da "máquina do empreendedorismo", com cerca de oito minutos, acompanhava o percurso de um desempregado (Figura 7). Começava com um patrão a despedir funcionários, aumentando os seus lucros e sobrecarregando o trabalho dos que ficam; um funcionário do Centro de Emprego cuja única ação é balbuciar e carimbar papéis; o desempregado numa espera angustiante, folheando jornais, ouvindo o tic-tac das contas por pagar (Figura 8).

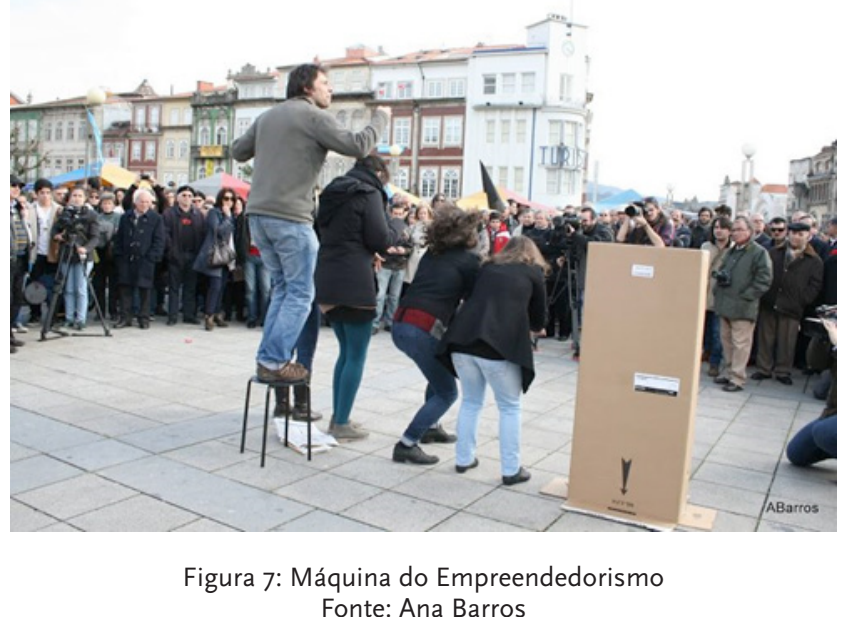

\footnotetext{
${ }^{21}$ Onde estão as relações de poder? Quais as estratégias utilizadas para perpetuar esse poder? Quem beneficia ou tira vantagem? O que esconde esse conceito? Qual a raiz do problema? Onde estão as suas contradições?

${ }^{22}$ Convocatória "Que se lixe a Troika": o povo é quem mais ordena. Retirado de http://queselixeatroika15setembro.blogspot.pt/p/que-se-lixe-troika-queremos-as-nossas.html
} 


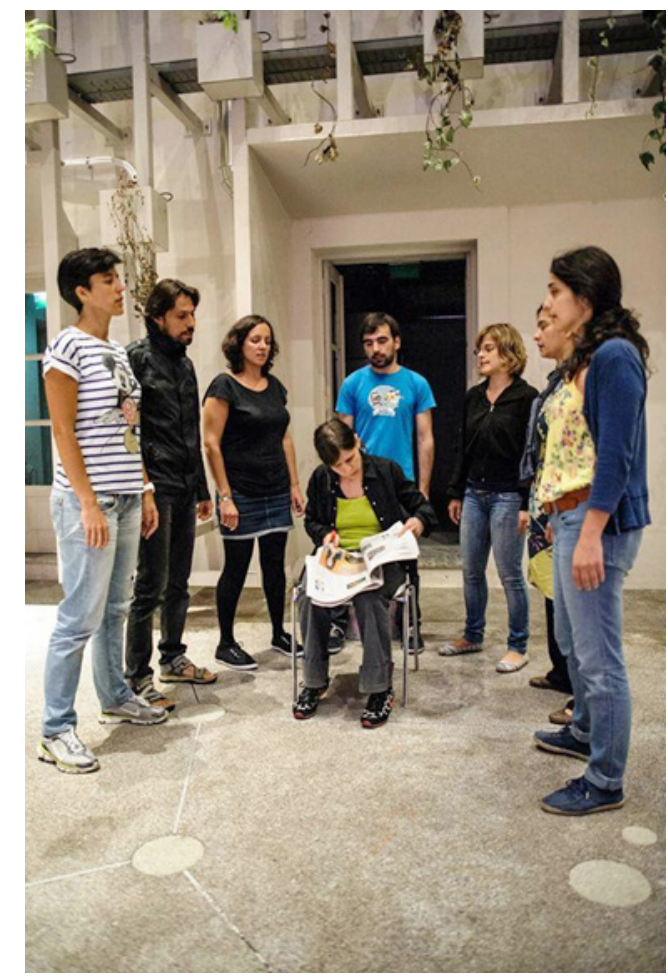

Figura 8: Máquina do Empreendedorismo, GNRation, Braga Fonte: Gonçalo Delgado

Nesse impasse, irrompe a canção "bem-vindo ao mundo encantado do emprego onde há reis, princesas, ladrões, desenvolve o teu potencial e serás um grande empreendedor"23. Iludido, o desempregado entra nesse mundo, sendo circundado por outros que o moldam para o tornar mais confiante, ativo, dinâmico. Pouco a pouco, o círculo torna-se num jogo do sempre-em-pé e o desempregado é empurrado de um lado para o outro, até que desiste e rompe a barreira à sua volta. Gritam-lhe - loser ${ }^{24}$ - e a cadeia recomeça: o patrão volta a despedir, os funcionários trabalham a triplicar e os lucros vão aumentando.

Apesar do processo de criação e reflexão coletiva desta máquina ter sido longo e, noutras ocasiões, ter até ocasionado um debate intenso ${ }^{25}$, a sua transposição para o espaço de uma manifestação não tinha surtido o efeito esperado: "bateram-se palmas e iniciou-se imediatamente o desfile pelo centro de Braga, ficando um amargo na boca". No final da marcha pela cidade, deu-se a concentração e "fomos convidados a subir ao palco, como sendo parte da organização. Foi bonito claro. À nossa frente tínhamos miIhares de pessoas, o centro estava cheio de cabeças, umas mais sérias, outras mais sorridentes, tudo vibrava enquanto cantávamos a Grândola" ${ }^{26}$ (Diário de bordo, 02/04/2013)

\footnotetext{
${ }^{23} \mathrm{~A}$ melodia da canção e a adaptação da letra corresponde à música da Leopoldina, Continente: "bem-vindo ao mundo encantado dos brinquedos, onde há reis, princesas, dragões..."

${ }^{24}$ Loser significa fracassado, em inglês.

${ }_{25}$ A "máquina do empreendedorismo" foi apresentada durante a Semana da Juventude em Agosto de 2013, em Braga, tendo sido seguida de um debate.

${ }^{26}$ Grândola é o título da canção de Zeca Afonso que foi senha da revolução dos cravos, em Abril de 1974.
} 


\section{Pipocas, PIPOCAS!}

Dia do Trabalhador, 1 de maio de 2013

"Amigo, se tu com 20 anos não consegues arranjar 100 euros por mês para pagar os estudos, então vais ter muitos problemas na vida, porque até a vender pipocas se arranja cem euros por mês". (Público, 02/04/2013) ${ }^{27}$

"Muitos dos que estão desempregados estão desempregados porque, ponto número um, não querem trabalhar e, ponto número dois, são maus a fazê-lo. (...). Não tenho problemas nenhuns em dizer que há muita gente em Portugal que não trabalha porque não quer, porque não sabe trabalhar ou porque não tem as competências necessárias". (Jornal i, 22/04/2013) ${ }^{28}$

Estas declarações ao jornal Público e ao Jornal $i$, são de Miguel Gonçalves, um popular empreendedor bracarense - à época embaixador do programa do Governo "Impulso Jovem", de incentivo à criação do seu próprio negócio - foram o rastilho para a intervenção do dia 1 de maio. A ideia surgiu de um dos membros do NTO: vamos distribuir pipocas no dia do Trabalhador, como forma de crítica a este discurso. O planeamento seguiu a lógica de sempre: reunir o grupo, aliciar pessoas que pudessem colaborar, adquirir o material necessário e partir para a rua. Como não havia nenhuma concentração sindical marcada para Braga - nem qualquer outro evento a assinalar a data - o NTO decidiu convocar uma concentração pelas redes sociais, contactando a plataforma "Que se lixe a Troika" que depressa se disponibilizou a colaborar na divulgação e na performance.

Na convocatória não referíamos a ação que estávamos a preparar, pois queríamos aproveitar o fator surpresa. No texto do evento no Facebook ${ }^{29}$, o NTO começava por recordar o 25 de Abril e o $1^{\circ}$ de Maio de 1974, em que as ruas se "encheram de alegria e de sonhos".

Para amanhã, dia do Trabalhador, não está nada marcado para Braga. Nenhuma celebração, nenhum protesto. Não interessa. A rua é NOSSA! Para isso, convidamos todos os cidadãos e cidadãs a ocuparem as ruas. Marcamos encontro na Avenida Central, junto às pirâmides, às 15h, para um piquenique comunitário. Tragam farnel, música, palavra e força. O sol vai brilhar. (...) É na reivindicação do espaço público que se faz a reivindicação da cidadania, da democracia e do futuro.

No dia marcado, vários elementos do grupo, engravatados, distribuíram um saco de pipocas junto com um manifesto lido publicamente (Figura 9).

\footnotetext{
${ }_{27}^{27}$ Palavras de Miguel Gonçalves ao jornal Público, de 2 de abril de 2013, numa sessão em que era apresentado como embaixador do Programa Impulso Jovem pelo Ministro Adjunto e dos Assuntos Parlamentares, Miguel Relvas, noticiada com o título "Relvas apresenta 'embaixador' que conheceu no YouTube".

${ }^{28}$ Excerto de uma entrevista de Miguel Gonçalves ao Jornal $i$, de 22 de abril de 2013 . A notícia original foi posteriormente retirada, mas uma reportagem no mesmo jornal, de 14 de outubro de 2013, informa que Miguel Gonçalves fora dispensado de embaixador do Programa Impulso Jovem e cita a notícia original.

${ }^{29}$ Retirado de https://www.facebook.com/events/32577801088289o/
} 


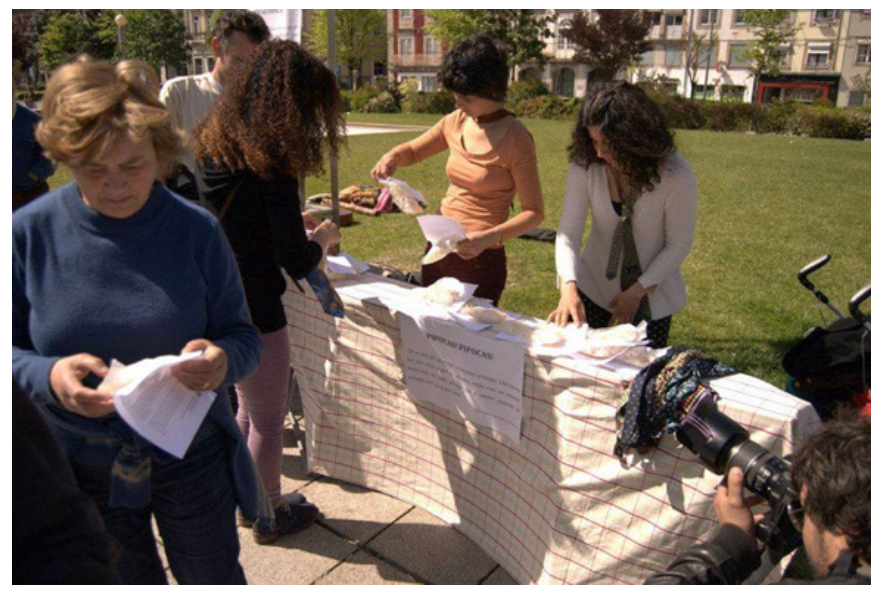

Figura 9: Banca para distribuição de pipocas Fonte: Aixa Gonzalez

No manifesto, para além das declarações acima referidas, lia-se: "Em nome dos $17,5 \%$ de desempregados, $40 \%$ deles jovens; em nome dos cerca de 100 mil portugueses que emigraram no último ano; dos milhares de alunos que abandonaram os estudos por falta de recursos; em nome de todos os trabalhadores precários e dos números que fogem das estatísticas e, acima de tudo, em nome de todas as pessoas por detrás destes números". Terminava com uma crítica à "falácia do empreendedorismo" ao discurso dos "super-heróis com iniciativa e atitude" que "culpabilizam o indivíduo" e desresponsabilizam o governo (Figura 10).

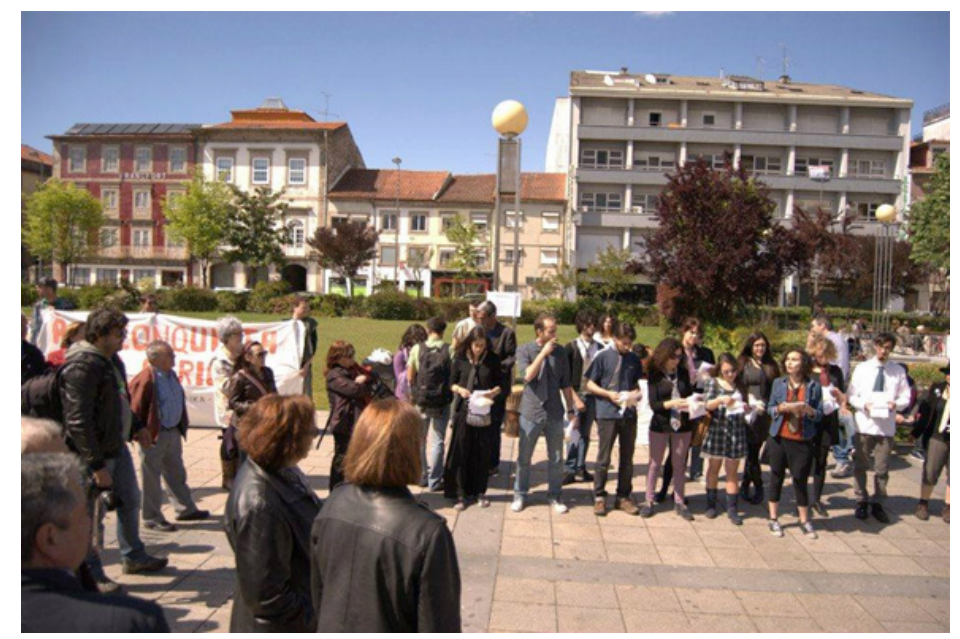

Figura 10: Leitura do manifesto Fonte: Vasco Santos

Por ter sido feito no dia anterior, o apelo à mobilização surtira um efeito diminuto, não se reunindo mais do que duas dezenas de pessoas, contudo, a sátira que tínhamos preparado conseguira atrair alguma atenção mediática ${ }^{30}$ (Figura 11) e o facto de

\footnotetext{
${ }^{30}$ Algumas das notícias publicadas em http://www.rtp.pt/noticias/cultura/teatro-do-oprimido-de-braga-oferece-pipocas-para-comemorar-dia-do-trabalhador_a647941

http://www.rum.pt/index.php?option=com_conteudo\&task=full_item\&item=35024\&section=4
} 
circularmos pela praça com o manifesto e as pipocas, conversando com as pessoas, gerou algum impacto local.

\section{Teatro do Oprimido lembra desempregados no 1.' de Maio}

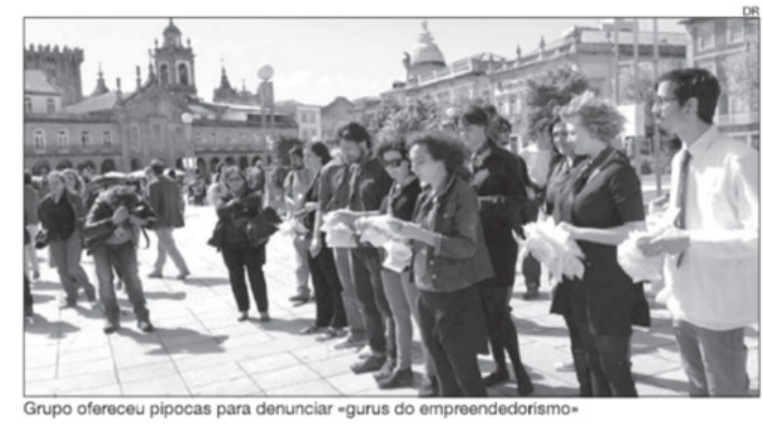

Jonge Ouvara

0 Núcleo de Teatro do Oprimido de Braga assinalou ontem o Dia do Trabalhador lembrando os $17,5 \%$ de desempregados (40\% deles jovens), os cerca de 100 mil portugueses que emigraram no último ano, os milhares de alunos que abandonaram os estudos por falta de recursos e os trabalhadores precários em Portugal.

Durante a ação, organizada na Avenida Central, o grupo resolveu oferecer pipocas aos transeuntes

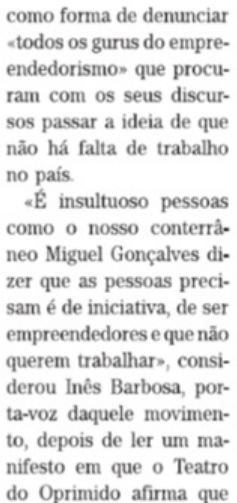

aé preciso terminar com esta falácia do empreendedorismo que culpabiliza $o$ indivíduo, desresponsabilizando as políticas sociais e económicas que têm vindo a ser impostas pelo Estadom.

Recorde-se que Miguel Gonçalves disse, quando foi apresentando pelo Governo como embaixador do programa Impulso Jovem, que se um jovem con 20 anos não consegue arranjar 100 euros por mês para pagar os estudos, «val ter muitos problemas na vida, porque até a vender pipocas se arranja $100 \mathrm{eu-}$ ros por mêss.

Segundo Inês Barbosa, este tipo de discurso, que sesquece as milhares de pessoas desempregadas $e$ as que abandonam o país por falta de recursos», não é só propalado na praça pública, é algo que está também a sinvadir s as universidades $\mathrm{e}$ isso eé muto graves. -É o espírito do capitalismo a falar. Não podemos cair no erro de responsaque são as pessoas culpadas por tudo o que acontece, que são culpadas do seu estado de desemprego, e desresponsabilizar o Estado dissos, referiu

A este grupo de ativistas juntou onúcleo de Braga do movimento "Que se lixe a troika", que aproveitou para distribuir a convidar para numa reunião, no dia 7 de maio, às $21 \mathrm{~h} 30$, na Velha-a-Branca, para preparar a manifestação agendada para o dia 1 de junho, em Lisboa, sob o lema "Povos unidos contra a troika"

Figura 11: Notícia publicada no Correio do Minho (jornal regional)

\section{PORQUÊ O PROTESTO ARTÍSTICO DE RUA? UMA ANÁLISE (QUASE) DESAPAIXONADA}

No ano de 2011 - "em que sonhámos perigosamente" - Zizek discursava num acampamento em Nova Yorque, para uma plateia imensa de manifestantes do Occupy Wall Street: "não se apaixonem por vocês mesmos, nem pelo momento agradável que estamos tendo aqui. Carnavais custam muito pouco, o verdadeiro teste do seu valor é o que permanece no dia seguinte, ou a maneira como a nossa vida normal e quotidiana será modificada" ${ }^{31}$.

Passaram mais de quatro anos desde as primeiras iniciativas do NTO Braga. Tudo parece já muito distante. O diário de bordo escrito em tom celebrativo, sem grande crítica ou sentido dialético, reflete o tom "apaixonado" com que foi escrito. Com a distância que o tempo permite, há lugar aqui para uma reflexão sobre as fragilidades, limitações e potencialidades das intervenções artísticas atrás relatadas e da aprendizagem,

\footnotetext{
${ }^{31}$ Retirado de http://blogdaboitempo.com.br/2011/10/11/a-tinta-vermelha-discurso-de-slavoj-zizek-aos-manifestantes-do-movimento-occupy-wall-street/; "O ano em que sonhamos perigosamente", 2011, Boitempo Editorial.
} 
"conscientização" e "emancipação intelectual" (Freire, 1975, 1979) que elas proporcionaram, em termos individuais e coletivos. Para tal, mobilizamos alguns trechos de um grupo focal realizado em 2014, com participação de quatro membros.

\section{A “ENERGIA INCONTORNÁVEL DA RUA”}

Acho importantes as intervenções na rua, é muito bom sentir pessoas que estão ali de paraquedas, ouvirem-nos e alguns deles até virem atrás de nós. (A)

A rua tem esse poder, é visceral a distância, está ali tudo ao teu lado (Q)

Em Braga tem mesmo de ser na rua... (J) $)^{32}$

Nos últimos anos, têm surgido novas possibilidades para o protesto virtual ou para a mobilização política (hashtags, denúncias em blogues, Facebook, Twitter) (Luque, Cerdá \& Sánchez, 2013). Contudo, apesar das suas limitações - visuais, espaciais, sonoras - e do seu grau de imprevisibilidade, a rua continua a configurar-se com um espaço vital para a tomada de consciência e intervenção coletiva. Procedendo a um duplo movimento de ocupação e abertura do espaço público (Bogad, 2005, p. 52), as performances de rua permitem aos protagonistas "ganhar voz na esfera pública por via da metafórica artística" (Mourão, 2013, p. 55) e, ao mesmo tempo, captar a atenção de pessoas que, estando "ali de paraquedas", se podem identificar e mobilizar. Não sendo totalmente fiáveis, os movimentos e reações da audiência - gargalhadas, aplausos, comentários - são um bom barómetro para medir o impacto das intervenções. Numa cidade como Braga, em que as mobilizações raramente atingem um elevando número de pessoas, o uso de ferramentas performativas em momentos de protesto tem uma importância acrescida, quebrando alguns silêncios e dando um significado à participação social e política.

\section{A URgênCIA E AS FlUtUAÇÕES Do CONTEXTo}

Uma das coisas que foi positiva nesse trabalho (Troca o Salazar pela Troika) foi ter mais tempo pra trabalhar, pra preparar, pra pesquisar (...) sedimentar o que se está a fazer (...) E as ações espontâneas resultam porque precisam de existir, são urgentes (..) mas fez-me pensar que precisavam de mais força, porque numa ou noutra, senti que a coisa aconteceu e foi com vento. (Q)

Naquela altura fizeram todo o sentido. Foi um momento em que houve varias manifs, era aquele o momento. Pedia aquelas intervenções. (J)

\footnotetext{
${ }^{32}$ Declarações registadas em entrevistas com grupos focais, realizadas em 2014.
} 
As duas formas são importantes. Há momentos que tem de ser agora. $(T)^{33}$

Esse agora refletia a urgência que se vivia na época, as manifestações sucediam-se e o clima era de alvoroço. As intervenções eram preparadas, muitas vezes, de um dia para o outro. A tónica era mais colocada na ação propriamente dita do que no que queríamos dizer com ela ou como nos relacionávamos com o tema. Por norma, esse tipo de intervenções não implica ensaios, "apresentando-se quase sempre com atuações únicas", uma forma de não perderem força (Mourão, 2013, p. 63). Porém, essa urgência causava ocasionalmente sensações de incompletude: "aquilo mexeu com as pessoas, mas faltou diálogo e feedback. Às vezes, vejo-me tentada a entrar numa onda de "agit-prop", provocar algo imediato nas ruas e nas pessoas, mas não é realmente suficiente." (Diário de bordo, 02/03/2013) Outro aspeto evidente é a influência das flutuações do contexto social e político nacional e europeu: quando a maré estava em cima, a energia subia, quando a mobilização esmorecia, também a nossa intervenção era diminuída ou interrompida.

\section{LINGUAGEM SIMBÓLICA, HUMOR E IRONIA}

A imagem não dá a papa" transmite algo que nos obriga a decifrar, a ler aquilo... (A)

A palavra é um processo racional, enquanto a imagem é muito mais emocional, mais subjetiva. Temos de fazer o trabalho todo. E cada um vê de forma diferente. (J)

A palavra é muito mais limitada... (Q)

Quando utilizamos a palavra estamos presos a determinados conceitos e significados, a imagem e o som entram de maneira mais rápida. $(T)^{34}$

O trabalho de construção-desconstrução da imagem é aqui destacado como um elemento fundamental para que a audiência se aproprie e construa os seus próprios significados. Como Boal (2009, pp. 88-89) escrevia, "as palavras são tão poderosas que, quando as ouvimos, obliteramos nossos sentidos através dos quais, sem elas, perceberíamos mais claramente os sinais do mundo. Sua compreensão é lenta porque necessitam de ser decodificadas; as sensações são de percepção imediata.". O papel do humor "para falar de coisas sérias", "sem ser de forma moralista", "aquele tipo de coisas que não assusta ninguém" (G.F.) é também destacado pelo grupo, assim como a ironia ou sarcasmo que "podem surpreender as pessoas e estimular a reflexão", impulsionando-as a fazer um "trabalho interpretativo" (Bogad, 2005, p. 53). Um dos objetivos mais

\footnotetext{
33 Declarações registadas em entrevistas com grupos focais, realizadas em 2014.

34 Declarações registadas em entrevistas com grupos focais, realizadas em 2014.
} 
repetidos na descrição das performances - mostrar as pessoas por detrás dos números - é também possibilitado pela linguagem teatral, ao concretizar o que é abstrato, ao desocultar o que permanece invisível, aquilo que, "por excesso de uso", deixou de despertar emoção (Boal, 1977, p. 71). Esse processo não se dá apenas externamente, mas no interior do grupo. O exercício de pensar como é que a crise afeta o nosso corpo, como é que seria a imagem da Troika, o som da dívida ou o ritmo da austeridade 35 permite que possamos interpelar as nossas experiências com aquilo que nos é dito, dando-lhe um sentido próprio, (re)construindo os significados sobre temas que nos dizem respeito: desemprego, emigração, precariedade. Fazê-lo em coletivo permite encontrar emoções e pensamentos dominantes, que nos podem devastar ou, por outro lado, pontos comuns e espaços de resistência. Referindo-se ao teatro-imagem, Bogad reforça como este pode “juntar as pessoas num espaço comum, a "expressar e desenvolver criativamente, não-verbalmente e dialogicamente as suas percepções do mundo, estruturas de poder e opressões" (2005, p. 49). Assim, essas estratégias, "despertam não só a consciência mas também os corpos para a ação política" (Delgado, 2013, p. 69).

\section{EMOÇÕES E CONSCIÊNCIA COLETIVA}

Há uma consciência de nós próprios, mas o facto de pertenceres a um grupo, também provoca uma consciência do coletivo (...) e do outro. (Q)

Sinto que o NTO me ajudou indiretamente, a integrar-me mais na cidade (...) na comunidade. (J)

Vejo também o grupo como funciona um grupo de amigos (...) Sei que posso contar com cada um. $\mathrm{E}$ isso também acalenta. $(\mathrm{Q})^{36}$

Ausentes durante muito tempo dos estudos sobre as dinâmicas dos movimentos sociais, as emoções provocadas pela participação num protesto e pelo envolvimento num grupo têm um papel relevante. Entusiasmo, esperança, confiança ou indignação, impotência, resignação estão presentes nas diversas fases e em todos os aspetos do protesto, podem ser meios, fins ou a combinação dos dois, podem manter as pessoas num determinado movimento como podem repeli-las. A identidade ou consciência coletiva não é só a partilha de valores ou objetivos comuns, mas também uma emoção, um afeto e lealdade em relação aos membros do grupo (Jasper, 2011). Ainda que a militância no NTO seja intermitente, que muitas pessoas tenham colaborado apenas de forma pontual, no final das ações sobressaía sempre um sentido de comunidade, identidade, "uma solidariedade afetiva" e "sentimentos de agência coletiva" (Bogad, 2005, p. 52; Juris, 2014, p. 242). A "emoção política" provocada pelas performances artivistas serve

\footnotetext{
${ }^{35}$ Esses exercícios de teatro-imagem foram feitos durante as oficinas "Imagens e sons da crise" ou "Juventude, trabalho e futuro" realizadas em vários locais do país e inspiradoras de parte das iniciativas do grupo.

${ }^{36}$ Declarações registadas em entrevistas com grupos focais, realizadas em 2014.
} 
assim de "consciência e mobilização social" tanto dos que nelas participam, como dos que a ela assistem (Mourão, 2013, p. 54).

\section{O PROTESTO-FESTA E OS RISCOS DO DESENQUADRAMENTO POLÍTICO}

As pessoas (incluindo nós) estão fartos de discursos e slogans sindicais, não lhes diz nada, não acrescenta nada. Este tipo de intervenção direta tem um impacto completamente diferente, as pessoas envolvem-se, revêem-se, sentem que estamos a falar de algo que lhes é próximo. (Diário de bordo: $14 / 11 / 2012)$

Este excerto expressa a difícil relação com outros atores políticos e com a linguagem produzida por eles. Referindo-se à "performatividade intrínseca" das manifestações organizadas pelos partidos e sindicatos, Soares $(2013$, p. 9) salienta as "decisões hierárquicas", "unidade cromática e icónica dos cartazes", "repetição de um pequeno repertório de palavras de ordem", "monotonia do ritmo", "rigorosa organização do desfile" e "rígida delimitação do espaço e do tempo" que tem por "objetivo a unificação ideológica", "promovendo a uniformização" e "deixando pouco espaço para a ação individual". Na mesma linha, Mourão (2013, pp. 40-43) aponta para a "previsibilidade" e "perda de vitalidade" e de "impacto" dessas manifestações, em contraponto com a "liberdade de ação", "a pluralidade de vozes", as "performatividades disruptoras da ordem habitual" e a "força menos domesticada de atores que saem à rua" nos protestos convocados pelos novos/novíssimos movimentos sociais.

Se é certo que o repertório de ação de partidos e sindicatos apresenta características que vão nesse sentido, não podemos deixar de refletir sobre a tendencial arrogância e preconceito em relação a esses atores políticos. Arrogância essa que, para além de não nos ter granjeado, em vários momentos, muito mais do que um "carnaval", não nos permitiu estabelecer pontes sólidas com eles, perdendo uma oportunidade de aprender com seus modos de organização, suas estratégias, sua capacidade de mobilização, organização, liderança e fidelização das militâncias. Numa era pós-política, de tendencial estetização das lutas sociais, de descrença generalizada em relação às instituições da democracia representativa (Delgado, 2013), essa foi talvez uma das maiores aprendizagens do grupo. O dilema expressado numa das descrições dos protestos - "nós não somos artistas, somos ativistas" - revela, em parte, a preocupação e a vontade de sobrepor os fins aos meios: a arte é a ferramenta, o objetivo é a intervenção política.

\section{CRÍTICA ESTÉTICA E CRÍTICA SOCIAL: O TEATRO DO OPRIMIDO E A EXPANSÃO DO FSPAÇO PÚBLICO}

Nos EUA, durante o Occupy, as montras das lojas eram decoradas de forma a simular vidros partidos, retratando os tumultos dos manifestantes; as t-shirts do Ché Guevara são vendidas de forma prolixa e não são poucas as marcas que invocam a revolução para 
publicitar os seus produtos. Para Krause (2011) a arte tem estado ao serviço do mercado liberal, a linguagem de resistência tem sido cooptada pelas corporações e pelas agências publicitárias e só um projeto "artisticamente radical", intimamente ligado a um projeto "politicamente radical", pode impedir que isso aconteça. Defendendo que a arte deve passar a estar sob controlo das pessoas e das comunidades, o autor argumenta que esta deve ser descentralizada, politizada e democratizada, acompanhando e alimentando um processo de transformação social.

$\mathrm{Se}$, por um lado, no decorrer dos protestos anti-austeridade, temos vindo a testemunhar a "inusitada dinamização do espaço público" (Ferreira, 2012), em que a cidade é palco da luta política e reclamada como direito coletivo (Harvey, 2008), em que a rua é "lugar simbólico de exibição de poder e contestação", possibilitando a "reapropriação do espaço público confiscado e privatizado" e configurando "uma nova relação entre cidadãos e cidade" (Antentas \& Vivas, 2012, pp. 77-80); por outro, temos vindo a assistir ao empobrecimento e redução do espaço público, "destituído de antagonismos", através da consolidação de um "pensamento único" acerca da crise e das políticas de austeridade (Cardina, 2012; Monteiro, 2011).

Nos exemplos de iniciativas do NTO, o espaço público - enquanto lugar de encontro e de contestação, como experiência social e de criação de uma identidade coletiva (Mateus, 2011) - foi o lugar escolhido para a produção e divulgação das suas críticas. As ações veiculavam várias críticas ao capitalismo, desdobradas numa crítica às políticas da austeridade enquanto programa ideológico; crítica ao uso da crise económica como forma de chantagem e como pretexto para a destruição do Estado Social; crítica ao discurso do empreendedorismo como estandarte do individualismo e panaceia para todos os males; crítica à reestruturação do trabalho apresentada como inevitável; crítica à divisão social da política, que a uns dá possibilidade de intervir e a outros a "oportunidade" de seguir. Neste sentido, formulamos aqui a hipótese de que a experiência do NTO articula e interpela os dois registos críticos que Boltanski e Chiapello definem como crítica estética e crítica social, sendo ambos fecundos para compreender e atuar nestas duas tendências - de dinamização e redução - do espaço público.

Em O novo espírito do capitalismo, aqueles autores sustentam que as fontes de indignação que historicamente têm alimentado a crítica têm-se mantido mais ou menos as mesmas ao longo dos dois últimos séculos. Elas são de quatro ordens: o capitalismo como fonte de desencantamento e de inautenticidade; como fonte opressão; como fonte de miséria e de desigualdades; e como fonte de oportunismo e de egoísmo. A crítica estética assenta, sobretudo, nas duas primeiras fontes de indignação, chamando a atenção para a estandardização e a mercantilização generalizada, e a crítica social apoia-se mais nas outras duas. De um modo geral, a crítica tende a privilegiar uma daquelas fontes, desenvolvendo a argumentação em torno da mesma.

Nos anos de 1960/70, a crítica estética e a crítica social estiveram associadas, caracterizando-se por dois conjuntos de reivindicações: do lado da crítica social, a diminuição da exploração e das desigualdades sociais, a consolidação dos dispositivos estatais de segurança e a representação mais forte dos assalariados no Estado; do lado 
da crítica estética, a denúncia do conservadorismo das instituições e a abolição das formas domésticas de dominação patriarcal; e, de um modo particular, a crítica ao Estado, considerado um servidor do capitalismo e um aparelho de exploração e opressão. Nesta conjuntura do Maio de 68, os movimentos de juventude reclamavam a liberdade e a autonomia, a espontaneidade, a autenticidade e a criatividade, coexistindo uma exigência de liberdade e autonomia (crítica estética) e uma exigência de segurança (crítica social), expressa com intensidade pelos movimentos operários no início da década de 1970, reclamando direitos económicos e sociais. O novo capitalismo que se começou a formar desde então apoiou-se, em boa parte, na crítica estética, incorporando as denunciações anti hierárquicas e as aspirações à autonomia exprimidas com força anteriormente, sobretudo nas manifestações de juventude. Assim, a partir dos anos 1980, o capitalismo beneficiou avidamente do enfraquecimento da crítica.

A experiência ativista do NTO Braga denuncia o capitalismo a partir da crítica social, ou seja, como fonte de opressão e desigualdades, focando sobretudo as questões materialistas (trabalho e emprego), mas articula-se, enquanto estratégia e também conteúdo, com a crítica estética: na forma de organização do grupo, no modo espontâneo de concretização das ações, na utilização da linguagem artística e pelo facto de focalizar em aspetos remetidos para segundo plano na crítica social: os "sonhos" engolidos pelo monstro da crise; os casos pessoais de quem está com as "mãos atadas"; a substituição dos números da crise por corpos humanos; ou a evocação utópica de mundos e sociedades melhores. Esta denúncia e crítica ao capitalismo e às suas consequências - em particular no mundo do trabalho - não se faz sem contradições. A exigência simultânea de "garantias e autonomia" requerida pela juventude do Maio de 68 é bem visível hoje. Se, por um lado, uma das principais "fontes de indignação" do grupo (e da juventude em geral) é dirigida à precariedade, castradora de projetos de vida a curto e longo prazo; por outro, os "lugares efetivos" ocupados pela geração anterior são muitas vezes refutados por uma juventude que balança entre a reivindicação de liberdade e segurança. Esse aspeto não poderá deixar de ser tido em conta nos processos de ação coletiva e do seu estudo sistemático em diversas áreas disciplinares.

A ação coletiva relatada neste trabalho, enquanto experiência artística e política, revelou-se como uma forma possível de expansão e dinamização do espaço público, por várias razões: por centrar a análise da realidade nas suas contradições; por permitir politizar a vida em comum; por servir de instrumento de auscultação popular; por tornar visível o invisível; por contribuir para desconstruir mitos e pensamentos dominantes; por usar a sátira, a metáfora e o humor para denunciar formas de manipulação. Contudo, a sua força reside na medida em que estiver articulada com outras estratégias, nunca como fim em si mesmo (Juris, 2014). Pelo menos no seio do grupo do NTO Braga, a experiência ativista produziu um sentido de solidariedade afetiva, de resistência e rebeldia, que ajudou a esbater o medo e a rejeitar o fatalismo estrategicamente alimentado pelas medidas austeritárias. 


\section{REFERÊNCIAS BIBLIOGRÁFICAS}

Abreu, A.; Mendes, H.; Rodrigues, J.; Gusmão, J. G.; Serra, N.; Teles, N.; Alves, P. D. \& Mamede, R. P. (2013). A crise, a troika e as alternativas urgentes. Lisboa: Tinta da China.

Antentas, J. M. \& Vivas, E. (2012). Planeta indignado: ocupando el futuro. Madrid: Sequitur.

Barbosa, I. \& Ferreira, F. I. (no prelo). O fascismo ainda mora cá dentro? O teatro-jornal e o discurso da austeridade. Educação, Sociedade e Culturas.

Boal, A. (1977). Técnicas latino-americanas de teatro popular: uma revolução copernicana ao contrário. Coimbra: Centelha.

Boal, A. (1980). Stop c'est magique. Rio de Janeiro: Civilização Brasileira.

Boal, A. (2009). A estética do oprimido. Rio de Janeiro: Garamond.

Bogad, L. M. (2005). Tactical carnival: social movements, demonstrations and dialogical performance. In M. Schutzman \& J. Cohen-Cruz (Eds.), A Boal Companion: Dialogues on Theatre and Cultural Politics (pp. 4658). Londres e Nova lorque: Routledge.

Boltanski, L. \& Chiapello, È. (1999). O novo espírito do capitalismo. São Paulo: Martins Fontes.

Braga, R. (2011). O pêndulo de Marx: Sociologias públicas e engajamento social. Utopía y Praxis, Latinoamericana, 16(52), 55-80.

Burawoy, M. (2006). Por uma sociologia pública. Revista de Ciências Sociais, 25, 9-50.

Cardina, M. (2012). Pensamento único. In Dicionário das crises e das alternativas. Cadernos de Ciências Sociais. Coimbra: Almedina/CES. Retirado de www.ces.uc.pt/observatorios/crisalt/index. php?id=6522\&id_lingua=1\&pag=6833

Chomsky, N. (2000). Los guardianes de la libertad. Propaganda, desinformación y consenso en los medios de comunicación de masas. Madrid: Crítica.

Correio do Minho (2012, 12 de outubro). Em Braga: Manifestação pela liberdade e democracia. Correio do Minho. Retirado de http://www.correiodominho.pt/noticias.php\%20...\%33 $/ \mathrm{p} \% 3 \mathrm{E} \% 33 \mathrm{C} /$ noticias. php?id $=64775$

Delgado, M. (2013). Artivismo y pospolítica. Sobre la estetizacion de las luchas sociales en contextos urbanos. Quaderns-e, 18 (2), 68-80.

Della Porta, D. \& Mattoni, A. (2014). Spreading protest: social movements in times of crisis. Reino Unido: ECPR Press.

Denzin, N. K. (2014). Interpretative autoethnography. Thousand Oaks: Sage.

Estanque, E.; Costa, H. A. \& Soeiro, J. (2013). The new global cycle of protest and the Portuguese case. Journal of Social Science Education, 1, 1-23.

Fals Borda, O. \& Rahman, M. A. (Eds) (1991). Action and knowledge: breaking the monopoly with participatory action research. New York: Intermediate Technology Publications/Apex.

Ferreira, C. (2012). Espaço público. In Dicionário das crises e das alternativas. Cadernos de Ciências Sociais. Coimbra: Almedina/CES. Retirado de www.ces.uc.pt/observatorios/crisalt/index. php?id=6522\&id_lingua $=1 \&$ pag $=6833$

Ferreira, A. C. (2012). Sociedade de austeridade e direito do trabalho de exceção. Porto: Vida Económica. 
Freire, P. (1975). Pedagogia do oprimido. Porto: Afrontamento.

Freire, P. (1979). Conscientização: teoria e prática da libertação. São Paulo: Cortez \& Moraes.

Freire, P. (1981). Criando métodos de pesquisa alternativa. In C. R. Brandão (Ed.), Pesquisa Participante (pp. 34-41). São Paulo: Brasiliense.

Furedi, F. (2006). Culture of fear revisited: risk-taking and the morality of low expectation. Londres: Continuum.

Harvey, D. (2008). The right to the city. New Left Review, 53, 23-40.

Jasper, J. (2011). Emotions and social movements: twenty years of theory and research. Annual Review of Sociology, 37, 285-303.

Jornal i, (2013, 22 de abril). Miguel Gonçalves deixou de ser embaixador do Impulso Jovem. Mas o governo não o avisou. Jornal i. Retirado de https://ionline.sapo.pt/artigo/349571/miguel-goncalves-deixou-deser-embaixador-do-impulso-jovem-mas-o-governo-nao-o-avisou?seccao=Portugal_

Juris, J. S. (2007). Practicing militant ethnography with the Movement for Global Resistance in Barcelona. In S. Shukaitis \& D. Graeber (Eds.), Constituent Imagination: Militant Investigations // Collective Theorization (pp. 164-178). Oakland: AK Press.

Juris, J. S. (2014). Embodying protest: culture and performance within social movements. In B. Baumgarten; P. Daphi \& P. Ullrich (Eds.), Conceptualizing Culture in Social Movement (pp. 227-247). Londres: Palgrave MacMillan.

Krause, A. (2011). Art as politics: the future of art and community. Noruega: New Compass Press.

Luque, S.; Martinéz Cerdá, J. F. \& Paredes Sánchez, M. O. (2013). O movimento 15M. Ações coletivas e voláteis no campo político. Comunicação e Sociedade, 23, 56-68. doi: 10.17231/comsoc.23 (2013).1613. Retirado de http://revistacomsoc.pt/index.php/comsoc/article/view/1613/1550

Madeira, C. (2013). Ciclos de "performatividades" nos movimentos sociais e as suas manifestações "artísticas". Trabalho apresentado no workshop "Protestos e movimentos sociais contemporâneos em Portugal", 20-21 de fevereiro, CIES, ISCTE, Lisboa.

Mateus, S. (2011). The public as social experience. Comunicação e Sociedade, 19, 275-286. doi: 10.17231/ comsoc.19 (2011).911. Retirado de http://revistacomsoc.pt/index.php/comsoc/article/view/911/871

Monteiro, S. (2011). O austeritarismo, mutação do pensamento único. In J. Reis \& João Rodrigues (Orgs.), Portugal e a Europa em crise (pp.195-199). Le Monde Diplomatique.

Mourão, R. (2013). Representações de contra-poder: performances artivistas no espaço público português. Dissertação de Mestrado, ISCTE, Lisboa, Portugal.

Neveux, O. (2014). Difficultés de l'émancipation. Remarques sur la théorie du «Théâtre de l'opprimé », Tumultes, 1(42), 191-207.

Público (2012, 14 de Novembro). Sete detidos e 48 feridos nos confrontos junto ao Parlamento, segundo a PSP. Público. Retirado de http://www.publico.pt/economia/noticia/greve-ao-minuto-1572391

Público (2013, 2 de abril). Relvas apresenta "embaixador" que conheceu no YouTube".

Público. Retirado de https://www.publico.pt/2013/04/02/politica/noticia/

relvas-apresenta-embaixador-que-conheceu-no-youtube-158989o

Ranciére, J. (2010). O espectador emancipado. Lisboa: Orfeu Negro. 
Soares, V. (2013). Espetacularidade e performatividade na cena contemporânea dos movimentos sociais portugueses. Trabalho apresentado no workshop "Protestos e movimentos sociais contemporâneos em Portugal", 20-21 de fevereiro, CIES, ISCTE, Lisboa.

Soeiro, J. (2012). Estou aqui por recear o meu futuro: juventude, precariedade e protesto, Configurações, 9, 103-119.

Soeiro, J.; Cardina, M. \& Serra, N. (2013). Não acredite em tudo o que pensa: mitos do senso comum na era da austeridade. Lisboa: Tinta da China.

Soeiro, J. (2015). A formação do precariado - Transformações no trabalho e mobilizações de precários em Portugal. Tese de Doutoramento. Universidade de Coimbra, Coimbra, Portugal.

VC (2007). Agitação e propaganda no processo de transformação social. São Paulo: Coletivos de Comunicação, Cultura e Juventude da Via Campesina.

\section{WEBGRAFIA}

Barbosa, I. troka o salazar pela troika. Retirado de https://www.youtube.com/watch?v=7T9Td_DgDZM.

Barbosa, I. "Máquina do Empreendedorismo", Manif 2 de março, Braga. Retirado de https://www.youtube. com/watch?v=eRS3HP8nTZQ

Boitempo (2011, 11 de outubro). A tinta vermelha: discurso de Žižek no Occupy Wall Street [Post em blogue]. Retirado de http://blogdaboitempo.com.br/2011/10/11/a-tinta-vermelha-discurso-de-slavoj-zizek-aosmanifestantes-do-movimento-occupy-wall-street/

CGTP - Confederação Geral dos Trabalhadores Portugueses, Pré-aviso de Greve Geral. Retirado de http:// www.cgtp.pt/materiais-greve-geral-14-11-2012

Forjaz, I. (2013, 1 de maio). Teatro do Oprimido de Braga oferece pipocas para comemorar Dia do Trabalhador. Retirado de http://www.rtp.pt/noticias/cultura/ teatro-do-oprimido-de-braga-oferece-pipocas-para-comemorar-dia-do-trabalhador_a647941

Krizo - Educação, Arte e Cidadania. Marcha das Mulheres Braga. Retirado de https://www.facebook.com/ ajkrizo

Krizo/ NTO Braga's Portfolio. Retirado de http://krizontobraga.foliohd.com/\#semana-da-juventude

Marques, P. (2012, 4 de março). Vítor Gaspar foi a Manteigas lembrar ensinamentos da avó. Retirado de http://www.asbeiras.pt/2012/03/vitor-gaspar-foi-a-manteigas-lembrar-ensinamentos-da-avo/

NTO-Braga. (2013, 1 de maio). Público - Evento criado por NTO-Braga. Retirado de https://www.facebook. com/events/325778010882890/

Óprima. Óprima! 2016 Encontro de Teatro do Oprimido e Ativismo | Casal Ventoso. Retirado de https:// oprima.wordpress.com

Precários Inflexíveis - Associação de combate à precariedade (2012, 13 de ourubro).

Que se lixe a Troika (2014, 15 de setembro). Que se lixe a Troika, o povo é quem mais ordena; Que se Lixe a Troika! Queremos as nossas Vidas! [Posts em blogue] Retirado de http://queselixeatroika15setembro. blogspot.pt/p/que-se-lixe-troika-queremos-as-nossas.html

Que se lixe a Troika! Manifestação Cultural. Retirado de http://www.precarios.net/?p=167 
Rádio Renascença/Sapo (2012, 13 de novembro). Movimentos sociais e estivadores na manifestação da CGTP. Retirado de http://rr.sapo.pt/informacao_detalhe.aspx?fid=25\&did=84964

Tvi24 (2012, 14 de novembro). Greve geral: retrato de um país em manifestação. TVI24. Retirado de http:// www.tvi24.iol.pt/sociedade/mabifestacoes/greve-geral-retrato-de-um-pais-em-manifestacao;

\section{NOTA BIOGRÁFICA}

Inês Barbosa é professora numa escola alternativa de educação pelas artes, no Porto. Mestre em Associativismo e Animação Sociocultural e doutorada em Ciências da Educação - Sociologia da Educação, pela Universidade do Minho com a tese "Crise, austeridade e ação coletiva: experiências de aprendizagem crítica com Teatro do Oprimido". Tem orientado as suas pesquisas em torno do Teatro do Oprimido (TO), juventude e precariedade. Interessa-se também pela aprendizagem em contexto associativo e ativista e pelas abordagens metodológicas de investigação militante e sociologia pública. É curinga de TO e dirigente associativa, organizando regularmente debates, oficinas, encontros políticos, festivais, etc. Frequenta atualmente uma Pós-Graduação em Performance, na Faculdade de Belas-Artes da Universidade do Porto.

E-mail: inesbarbosa83@gmail.com

Universidade do Minho, Campus de Gualtar, 4710-057 Braga, Portugal

Fernando Ilídio Ferreira - Professor Associado do Departamento de Ciências Sociais da Educação, do Instituto de Educação, Universidade do Minho, Portugal, onde leciona desde 1992. Concluiu o doutoramento em Estudos da Criança, em 2003, e é atualmente membro integrado do Centro de Investigação em Estudos da Criança. Leciona várias unidades curriculares em cursos de graduação e pós-graduação, como Sociologia da Educação, Políticas Educativas, Associativismo e Animação Sociocultural, e Metodologias de Investigação. É orientador científico de dissertações e teses, nas áreas de Ciências da Educação e Estudos da Criança. Publica nestas áreas e participa em projetos nacionais e internacionais no âmbito da educação de adultos, formação de professores, associativismo e cidadania, e estudos da infância. É consultor em escolas e centros de formação e militante associativo no campo da educação e da cidadania.

E-mail: filidio@ie.uminho.pt

Universidade do Minho, Campus de Gualtar, 4710-057 Braga, Portugal

* Submetido: 15-10-2016

* Aceite: 23-01-2017 